\title{
The effect of submersion denture base acrylic resin in a betel leaf extract solution against growth candida albicans
}

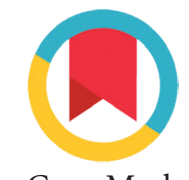

\author{
Ardiansyah S. Pawinru, ${ }^{*}$ Andi Izham
}

\section{Abstract}

Objective: Microorganisms often found in the oral cavity are candida albicans; compared to all the other microorganisms present in the oral cavity their presence is much larger, approximately $40 \%$. Candida albicans can penetrate the acrylic resin that can infect the soft tissue and is the cause of denture stomatitis; therefore, the disinfection pf denture base is an important step to be carried out. The purpose of this study is to determine the effect of submersion denture base acrylic resin derived from betel leaf extract solution over the growth of candida albicans.

Material and Methods: This research is an experimental laboratory study with a longitudinal design (follow-up). The sampling method used is total sampling. This study used a sample of 12 pieces of denture base material of acrylic resin to be suspended into candida albicans fungus for $1 \times 24$ hours at $37^{\circ} \mathrm{C}$.

Results: The results derived for the number of candida albicans colonies in the acrylic resin denture base soaked in betel leaf extract solution are as follows: control solution dilution $10^{-1}$ (with $2.5 \%$ concentration, total colony count is 2), and the result is $2.0 \times 10^{1} \mathrm{CFU} / \mathrm{ml}$; control solution dilution $10^{-2}$ (total colony 355 ), and the result is $3.55 \times 10^{4} \mathrm{CFU} / \mathrm{ml}$; control solution dilution $10^{-3}$ (total colony 62 ), and the result is $6.2 \times 10^{4} \mathrm{CFU} / \mathrm{ml}$. Conclusion: Betel leaf extract (Piper Linn) can inhibit the growth of candida albicans on the acrylic resin denture base; a disinfectant solution mixed with $5 \%$ betel leaf extract (Piper Linn) can be used as a disinfectant solution to treat the acrylic resin denture.
Department of Orthodontics, Faculty of Dentistry, Hasanuddin University, Makassar, Indonesia

*Corresponding to: Ardiansyah S. Pawinru, Department of Orthodontics, Faculty of Dentistry, Hasanuddin University, Makassar, Indonesia

Pawinru190879@gmail.com

Received: 24 0ctober 2017 Revised: 5 November 2017 Accepted: 13 November 2017 Available online: 1 December 2017

Keyword: Betel leaf ekstract solution, Candida albicans, Denture base acrylc resin

Cite this Article: Izham A, Pawinru AS. The effect of submersion denture base acrylic resin in a betel leaf extract solution against growth candida albicans. Journal of Dentomaxillofacial Science 2(3): 183-186. D0l: 10.15562/jdmfs.v2i3.660

\section{Introduction}

Denture is a prosthesis that replaces some or all of the original missing teeth and surrounding tissue. The purpose of making the prosthesis is to rejuvenate the function, appearance, comfort, and health which were impaired as a result of tooth loss. One part of a denture is the base plate. The denture base plate is part of the artificial tooth contacting the oral mucosa, attached to and supporting the artificial tooth element, channeling the occlusal pressure to the support network and providing retention and stability to the artificial tooth. More than $95 \%$ of denture plates are made of acrylic resin material. ${ }^{1}$

Acrylic resin material has one of the properties that absorbs water slowly over a period of time; the absorption occurs through diffusion of water molecules according to the law of diffusion. ${ }^{2}$ Microorganisms that have a large presence in the oral cavity are candida albicans (about 40\%) as normal parts of mouth flora. Candida albicans can penetrate acrylic resins to infect soft tissue and cause denture stomatitis; therefore, denture disinfection is an important factor to do. ${ }^{3}$ Candida albicans is a normal flora contained in the oral cavity; if the balance is disrupted, fungus becomes a pathogen and causes infection in the oral cavity of candidiasis. ${ }^{4}$ Oral candidiasis is usually a secondary infection that accompanies other medical conditions. A mixture of candida species can be found in oral candidiasis with candida albicans being the primary cause of their presence. ${ }^{5}$

Traditionally, betel leaf is used as a medicine for thrush, sore throat, cough medicine, eye wash, whitish medicine, bleeding in the nose/ nosebleed, accelerating wound healing, eliminating bad breath, and treating toothache. Betel leaf has a distinctive aroma because it contains $1-4 \%$ essential oils, protein, fat, carbohydrate, calcium, phosphorus, and vitamin $\mathrm{A}, \mathrm{B}, \mathrm{C}$ of sugar iodine. Of these various ingredients, in essential oils there are natural phenols that have very strong antiseptic power (bakterisid and fungisid). ${ }^{6}$ In general, betel leaves contain essential oils that have up to $4.2 \%$ of phenyl propanoid compounds and tannins. This compound is antimicrobial and strongly antifungal and can inhibit the growth of several types of bacteria such as Escherichia coli, Salmonella sp, Staphylococcus aureus, Klebsiella, Pasteurella and can kill candida albicans.? 
Therefore, the researcher is interested to examine the effect of immersion base of acrylic resin base in the betel leaf extract solution on the growth of candida albicans.

\section{Material and Methods Research procedure}

Preparation of acrylic resin denture samples: preparation of denture acrylic resin is done by the technique. The sample used as many as 12 pieces with a diameter of $2 \mathrm{~mm}$. Making betel leaf extract: the making of betel leaf extract is done with dried betel leaf. After carrying out these two steps, the dried leaves are pollinated, and ground, to obtain betel leaf extract. Media creation: Potato Dextrose Broth (PDB), a total of 3.1 grams of GDP media was put into $100 \mathrm{ml}$ of aquades which was then heated to dissolve. This was further sterilized on autoclave at $121^{\circ} \mathrm{C}$ at 2 atm pressure for 15 minutes; a total of 7.8 grams of PDA media is fed into $200 \mathrm{ml}$ of aquades and then heated to dissolve. This was further sterilized on autoclave at $121^{\circ} \mathrm{C}$ at $2 \mathrm{~atm}$ pressure for 15 minutes. Preparation of betel leaf extract solution concentration: this research used solutions with concentrations of $2.5 \%, 5 \%$, and $10 \%$. Solution with a concentration of $10 \%$ is made by inserting $2 \mathrm{ml}$ of betel leaf extract into elemeyer tube, then aquades was added enough to reach $100 \mathrm{ml}$. The same treatment is used to make other concentrations. Rejuvenation of candida albicans fungus: a total of 1 ose candida albicans cultures are fed into $100 \mathrm{ml}$ of GDP media; they were then incubated in rotation shaker for $1 \times 24$ hours. Immersing denture acrylic resins on candida albicans media: the sterilized denture acrylic resin is introduced into a $100 \mathrm{ml}$ medium of GDP and subsequently into the medium containing $1 \mathrm{ml}$ of candida abicans isolate (1\%). Media was then subjected to rotation in a shake for $1 \times 24$ hours. Immersion denture acrylic resin on betel leaf extract with concentration of $2.5 \%, 5 \%$, and $10 \%$ : nine acrylic resin dentures are divided into three groups, and one is used as a control sample. All three groups were immersed in $100 \mathrm{ml}$ of betel leaf extract solution with different concentrations $(2.5 \%, 5 \%$, and $10 \%)$ for 8 hours at room temperature. The control sample was immersed in $10 \mathrm{ml}$ of sterile distilled water. Calculation of candida albicans colonies: acrylic resin glycoplasm that has been soaked in the betel leaf extract is then fed into the streilaquades and vortexed. The solution is then carried out for a series of dilutions up to $10^{-3}$. A quantity of $1 \mathrm{ml}$ each diluted solution sample was poured into petri dish and PDA media was poured into dish additionally. After the media solidified, it was kept in the incubator for $1 \times 24$ hours at $37^{\circ} \mathrm{C}$.

\section{Tools and Measurement}

Potato Dextrose Agar (PDA) is used as a tissue culture medium in bacteria and fungi, one of which used in this research is candida albicans. Calculation of the number of colonies can be obtained by a device called a colony counter or by using the formula:

Fungal numbers $=\frac{\begin{array}{c}\text { number of } \\ \text { fungal colonies }\end{array}}{\text { calculated volume }}$

Fungal figures obtained can be used to determine the antifungal power at each concentration by calculating KHM. Calculation of KHM is done using the following formula:

$$
K H M=100 \% \quad \frac{\mathrm{AJT} \times 100 \%}{\mathrm{AJK}}
$$

Information:

AJT :Number of fungi at a certain concentration in units, CFU/ml

AJK: Fungal number in the control solution in units, $\mathrm{CFU} / \mathrm{ml}$

\section{Data Analysis}

The data obtained were analyzed using analysis of variance (ANOVA).

\section{Results \\ Characteristics of the study sample}

In this study, the samples used were 12 dosage acrylic resin bases. Nine samples were given treatment (soaked in betel leaf extract solution), and 3 samples were used as controls. The immersion process was divided into three groups with different concentrations: $2.5 \%, 5 \%$, and $10 \%$; each of the samples were diluted up to $10^{-3}$. Each group consists of three samples that have been controlled for size and base diameter. The base length is $10 \mathrm{~mm}$, the base width is $10 \mathrm{~mm}$, and the base thickness is $20 \mathrm{~mm}$.

\section{Data Analysis}

Based on the research that has been done, the number of colonies of candida albicans fungi located at the base of the denture are presented in table 1 and table 2. This study uses the method of calculating bacteria/fungi by Standard Plate Count (SPC), that is, by using the formula:

Fungal numbers $=\frac{\begin{array}{c}\text { number of } \\ \text { fungal colonies }\end{array} \times \frac{1}{\text { Dilution factor }}}{\text { calculated volume }}$ 


$$
\begin{aligned}
\text { Fungal numbers } & =\frac{\begin{array}{c}
\text { number of } \\
\text { fungal colonies }
\end{array}}{\text { calculated volume }} \\
& =\frac{2 \times \frac{1}{10^{-1}}}{1} \\
& =2 \times 10^{1} \\
& =2,0 \times 10^{1} \mathrm{CFU} / \mathrm{ml}
\end{aligned}
$$

$$
\text { Fungal numbers }=\frac{\begin{array}{c}
\text { number of } \\
\text { fungal colonies }
\end{array} \times \frac{1}{\text { Dilution factor }}}{\text { calculated volume }}
$$

$$
\begin{aligned}
& =\frac{355 \times \frac{1}{10^{-2}}}{1} \\
& =355 \times 10^{2} \\
& =3,55 \times 10^{4} \mathrm{CFU} / \mathrm{ml}
\end{aligned}
$$

Fungal numbers $=\frac{\begin{array}{c}\text { number of } \\ \text { fungal colonies }\end{array}}{\text { calculated volume }}$

$$
\begin{aligned}
= & \frac{62 \times \frac{1}{10^{-3}}}{1} \\
= & 6210^{3} \\
= & 6,2 \times 10^{4} \mathrm{CFU} / \mathrm{ml}
\end{aligned}
$$

Table 1 Distribution of Candida albicans colonies that are immersed in a solution of betel leaf extract with different concentration of solution ( $\mathrm{N}=9$ )

Number of colonies of Candida albicans on denture base of acrylic resin which has been soaked in a solution of betel leaf extract

\begin{tabular}{lccc}
\cline { 2 - 4 } Dilution & $\mathbf{2 . 5 \%}$ & $\mathbf{5 \%}$ & $\mathbf{1 0 \%}$ \\
\hline $10^{-1}$ & 2 & - & - \\
$10^{-2}$ & - & - & - \\
$10^{-3}$ & - & - & - \\
\hline
\end{tabular}

Table 2 The distribution of the amount of candida albicans colonies immersed in the control solution (aquades)

\begin{tabular}{ll}
\hline Dilution & $\begin{array}{l}\text { The number of candida albicans colonies on the denture } \\
\text { base of the acrylic resin has been immersed in the } \\
\text { control solution }\end{array}$ \\
\hline $10^{-1}$ & TBUD \\
$10^{-2}$ & 355 \\
$10^{-3}$ & 62 \\
\hline
\end{tabular}

Table 1 shows that solution in dilution $10^{-1}$ with $2.5 \%$ concentration and colony count 2 , dilution $10^{-2}$ with $5 \%$ concentration, and dilution $10^{-3}$ with $10 \%$ concentration did not reveal the presence of candida albicans. In table 2 it can be seen that at dilution $10^{-1}$ the number of colonies is not biased to be calculated (TBUD), whereas at dilution $10^{-2}$ the number of colonies were as many as 355 , and at dilution $10^{-3}$ the number of colonies were as many as 62 candida albicans. Based on the explanation given in the above table it can be concluded that the diluted sample with a certain dilution rate has a varying total of microbes. Higher dilution rates result in a higher number of colonies.

\section{Discussion}

This study used a sample of 12 pieces of denture base material acrylic resin to be suspended into candida albicans fungus for $1 \times 24$ hours at $37^{\circ} \mathrm{C}$. All samples were divided into three groups, each group consisting of three samples. Each sample was immersed in a solution of betel leaf extract with different concentrations of $2.5 \%, 5 \%$, and $10 \%$ for 8 hours. Three samples were immersed in aqueous solutions as controls. Furthermore, each sample was shaken with a vortex mixer for 1 minute, and a series of dilutions dilated up to $10^{-3}$. Then from each dilution test $1 \mathrm{ml}$ of the solution was taken and was dripped on the Petri Potato Dextrose agar (PDA) dish and kept in the incubator for $1 \times 24$ hours at $37^{\circ} \mathrm{C}$. Analysis of the number of colonies in each petridish was done by Standard Plate Count (SPC) calculation method.

Based on the research that has been done, the effect of dilution on the number of colonies (fungi) is presented in table 1 and table 2. Results presented in table 1 show that solution with dilution $10^{-1}(2.5 \%$ concentration, colony count 2$)$, solution with dilution $10^{-2}$ (concentration $5 \%$ ), and solution with dilution $10-3$ (10\% concentration) did not contain or show candida albicans. Results presented in table 2 show that at dilution $10^{-1}$ the number of colonies is not biased to be calculated (TBUD), whereas at dilution $10^{-2}$ the number of candida albicans colonies was as many as 355 and at dilution $10^{-3}$ as many as 62 . The result of minimal barrier computation (KHM) as presented in table 1 is that a dilution of $10^{-1}$ with $2.5 \%$ concentration yielded a colony count of 2 , with the result being " $2.0 \mathrm{x}$ ", and table 2 shows that dilution of $10^{-2}$ yielded a colony count of 355 with the result being and at dilution $10^{-3}$ the colony count was 62 , with the result being $\mathrm{CFU} / \mathrm{ml}$. 


\section{Conclusion}

Betel leaf extract (Piper Linn) can inhibit the growth of candida albicans on the denture base of acrylic resin; betel leaf extract (Piper Linn) $5 \%$ is a minimal anti-fungal solution that can be used as a disinfectant solution to clean acrylic resin denture. Betel leaf extract (Piper Linn) can be used as a denture disinfectant solution, but not in high concentrations; further research is needed to verify the efficacy of using betel leaf extract (piper linn) as a disinfectant solution to clean denture acrylic resin and assess the effect of the duration of immersion of denture acrylic resin in the disinfectant solution, including changes in the shape and texture at the denture base.

\section{Conflict of Interest}

The authors report no conflict of interest

\section{References}

1. Rahman EF. Efektivitas ekstrak daun dewa terhadap petumbuhan candida albicans pada plat dasar gigi tiruan resin akrilik. Jurnal Kedokteran Gigi Jurnal Ilmiah Universitas Sultan Agung; 2010;48: 1-13.
2. David. Perubahan warna lempeng resin akrilik yang di rendam dalam larutan desinfektan sodium hipoklorit dan klorhexidin. Dental Journal 2005: 36-40.

3. Endang W. Pengaruh ekstrak Graptophyllumpictum terhadap pertumbuhan candida albicans pada plat gigi tiruan resin akrilik. Indo J Dent 2008;15: 187-191.

4. Rachmi FH. The inhibition response of Alpiniagalangarhizome extract $10 \%$ and Alpiniapurpuratarhizome extract 10\% toward the growth of candida albicans. Journal Dentistry 2.

5. Lakshmi A, Leepel. Efek penambahan glukosa pada saburoud dextrose terhadap pertumbuhan candida albicans. Indo J Dent 2009;16: 58-63.

6. Atiek S. Uji pendahuluan efek kombinasi anti jamur infuse daun sirih, kulit delima, dan rimpang kunyit terhadap jamur candida albicans. Makara 2002;6: 149-151.

7. Julia R. Daya anti mikroba ekstrak dan fraksi daun sirih merah (piper betle Linn). Jurnal Ilmu Dasar 2011;12: 6-12.

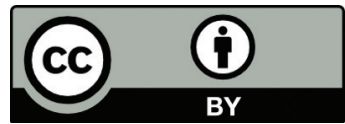

This work is licensed under a Creative Commons Attribution 